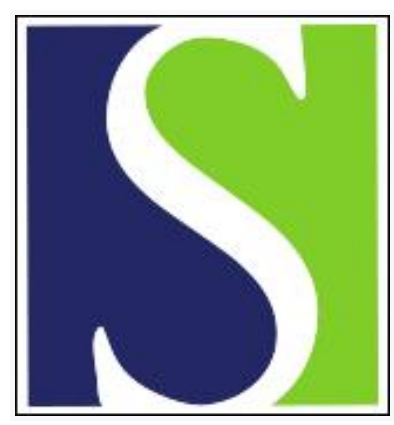

Scand J Work Environ Health 1993;19(1):29-34

https://doi.org/10.5271/sjweh.1507

Issue date: $01 \mathrm{Feb} 1993$

Chromosome aberrations in lymphocytes of high-voltage laboratory cable splicers exposed to electromagnetic fields. by Skyberg K, Hansteen IL, Vistnes Al

Affiliation: Medical Department, Alcatel STK AS, Oslo, Norway.

This article in PubMed: www.ncbi.nlm.nih.gov/pubmed/8465169

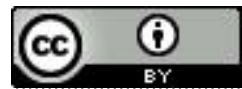




\title{
Chromosome aberrations in lymphocytes of high-voltage laboratory cable splicers exposed to electromagnetic fields
}

\author{
by Knut Skyberg, MD, ${ }^{1}$ Inger-Lise Hansteen, MSc, ${ }^{2}$ Arnt Inge Vistnes, $\mathrm{PhD}^{3}$
}

\begin{abstract}
SKYBERG K, HANSTEEN I-L, VISTNES AI. Chromosome aberrations in lymphocytes of high-voltage laboratory cable splicers exposed to electromagnetic fields. Scand J Work Environ Health 1993; 19:29-34. Thirteen high-voltage laboratory employees and 20 referents participated in a cross-sectional, matched-pairs study of cytogenetic damage. During cable testing the workers were exposed to static, alternating, or pulsed electric and magnetic fields. The alternating magnetic field levels of $50 \mathrm{~Hz}$ were 5-10 $\mu \mathrm{T}$, occasionally much higher. Chromosome aberrations, sister chromatid exchanges, and aneuploidy were studied in peripheral blood lymphocytes. In addition, chromosome aberrations were investigated in lymphocyte cultures treated with hydroxyurea and caffeine, to inhibit deoxyribonucleic acid synthesis and repair. Among seven smoking laboratory employees the mean number of chromosome breaks/ 200 cells was 2.3 , as compared with 0.7 for the job-matched referents. The comparable figures for inhibited cultures were 12.0 versus 6.0 . No increase was detected in nonsmokers with either method. The other genetic parameters showed no differences between the exposed workers and the referents. The results support, to some extent, the hypothesis of an increased risk of genotoxic effects among high-voltage laboratory workers.
\end{abstract}

Key terms: cross-sectional study, genotoxic effect, magnetic fields, spark discharges.

During the last decade several studies have focused on adverse health effects from exposure to electromagnetic fields (1). Some epidemiologic studies of workers exposed to electromagnetic fields have shown an increased risk of leukemia, and some found an elevated risk of brain tumors among "electrical workers" (2). In a mortality study of workers exposed to electromagnetic fields, Milham (3) found elevated mortality from lymphatic and hematopoietic cancers. The highest risk was observed for power station operators (proportionate mortality ratio 195). It has also been suggested that pulsed magnetic fields produce teratogenic effects in chicken embryos $(4,5)$

In a high-voltage laboratory in Oslo, the management and workers were concerned about several cases of cancer (although at various sites) among the employees. However, the number of workers ever employed in the laboratory was not sufficient for a cancer incidence study. In a cytogenetic study of oilexposed cable workers (6) a subgroup consisting of four cable test splicers from the laboratory showed signs of increased chromosome aberrations in blood lymphocytes. The present study was performed to investigate this observation further. The hypothesis

\footnotetext{
1 Medical Department, Alcatel STK AS, Oslo, and National Institute of Occupational Health, Oslo, Norway.

2 Department of Occupational Medicine, Telemark Central Hospital, Porsgrunn, Norway.

3 Institute of Physics, University of Oslo, Blindern, Oslo, Norway.
}

Reprint requests to: Dr K Skyberg, National Institute of Occupational Health, PB 8149 Dep, N-0033 Oslo, Norway. was that high-voltage cable testing may be genotoxic, as indicated by an increased number of chromosome breaks.

\section{Exposure}

Exposure to electromagnetic fields was estimated from information on work practice, obtained through five interviews, and from direct measurements, using four different probes. Great care was taken in the construction of the equipment, in the calibration procedures, and in the software integration procedures of the 25.4-MHz sampled signal (for high-frequency signals after pulse testing) to obtain reliable measurements.

The workers were exposed to electromagnetic fields during three different main types of cable testing, namely, direct current (DC) tests, alternating current (AC) tests, and pulse tests. The tests were typically performed on a piece of cable $15-\mathrm{m}$ long.

In the $\mathrm{DC}$ and $\mathrm{AC}$ testing, high voltages (up to $1000 \mathrm{kV}$ DC or $900 \mathrm{kV} 50 \mathrm{~Hz} \mathrm{AC}$ ) were used across the insulation of the cable. Periodically, the cable was heated by the circulation of a high current (DC or $50 \mathrm{~Hz} \mathrm{AC}$ ) up to $2000 \mathrm{~A}$ through the cable. During high-voltage DC or AC testing, there was an estimated static or alternating electric field of 5$10 \mathrm{kV} \cdot \mathrm{m}^{-1}$ at a distance of $1 \mathrm{~m}$ above the floor of the test hall. During heating, there was either a static or $50-\mathrm{Hz}$ alternating magnetic field of about 5 $15 \mu \mathrm{T}$ in the control room and in the resting room for test splicers. Workers sometimes touched the cable during the testing and could then be exposed to 
a magnetic field of $\sim 500 \mu \mathrm{T}$ (body) and $\sim 10000 \mu \mathrm{T}$ (hand).

During pulse testing, a voltage pulse of up to 2000 $\mathrm{kV}$ was suddenly applied to the cable. Typically, the rise time for the voltage across the insulation was 1$3 \mu \mathrm{s}$, and the half-time for the following exponential decay was $50 \mu \mathrm{s}$. The peak current during the pulse was about $10000 \mathrm{~A}$. During such testing an electric field of up to about $2 \mathrm{kV} \cdot \mathrm{m}^{-1}$ was measured in the shielded control room. The field oscillated in a "ringing" pattern for a few microseconds with a broad range of frequencies in the $0-3 \mathrm{MHz}$ range. Magnetic field pulses in the control room were measured to be about $20 \mu \mathrm{T}$ with a maximum rate of change in the magnetic field $\left(\mathrm{dB} \cdot \mathrm{dt}^{1)}\right.$ of about $8 \mathrm{~T} \cdot \mathrm{s}^{-1}$. During and after the testing, the workers often felt spark discharges. Especially DC testing often resulted in charged objects that gave sparks at touch.

It has been difficult to get a reliable picture of the exposure time for different fields for each category of employees. With few exceptions, there was only moderate testing activity during the last weeks prior to the blood sampling. AC testing, followed by DC testing, was probably the most dominant test in this period. During AC and DC testing, the various fields were present for several hours every day. During pulse testing, a worker might produce up to 100 pulses during a workday, but for most workers the mean exposure time to such pulses was less than $1 \mathrm{~d}$ a week. Test splicers were definitely more exposed to electromagnetic fields during $\mathrm{AC}$ and $\mathrm{DC}$ testing than the engineers were, and probably also during pulse testing. Spark discharges seemed to be more common for the test splicers than for the engineers.

\section{Subjects and methods}

The study was cross-sectional with additional retrospective information about exposure. It compared all of the employees in the high-voltage laboratory, on 1 June 1990, at Alcatel STK in Oslo to matched referents in pairs or triplets. Four engineers, one foreman, and one engineering assistant (treated as one group, called "engineers") and seven test splicers participated. To match the engineers, other office employees ("job-matched" referents) were selected. For each test splicer, two referents were selected. One reference group ("job-matched") consisted of other production workers. In addition, a second reference group of office workers was selected. The referents were chosen according to the following matching criteria: same age ( \pm 3 years) and same smoking status at the time of the examination (present smoker/nonsmoker). The referents were not exposed to any possible genotoxic chemicals at work and had no more occupational exposure to electromagnetic fields than the general population. All of the exposed subjects and the referents received a questionnaire with which to record occupational and nonoccupational exposures with possible influence on chromosome damage.

Table 1 shows the characteristics of the exposed and reference groups. The test splicers had a higher

Table 1. Description of the study groups.

\begin{tabular}{|c|c|c|c|c|c|}
\hline & $\begin{array}{c}\text { All exposed } \\
(\mathrm{N}=13) \\
(\mathrm{N})\end{array}$ & $\begin{array}{l}\text { Referents } \\
(\mathrm{N}=13) \\
(\mathrm{N})\end{array}$ & $\begin{array}{c}\text { Test splicers } \\
(\mathrm{N}=7) \\
(\mathrm{N})\end{array}$ & $\begin{array}{c}\text { Referents } \mathrm{s}^{\mathrm{a}, \mathrm{b}} \\
(\mathrm{N}=7) \\
(\mathrm{N})\end{array}$ & $\begin{array}{l}\text { Office referents } \\
\qquad \begin{array}{c}\mathrm{b}=7) \\
(\mathrm{N})\end{array}\end{array}$ \\
\hline \multicolumn{6}{|l|}{ Work category } \\
\hline $\begin{array}{l}\text { Engineers } \\
\text { Test splicers }\end{array}$ & $\begin{array}{l}6 \\
7\end{array}$ & . & 7 & . & . \\
\hline \multicolumn{6}{|c|}{ Employment time in company (years) } \\
\hline $\begin{array}{l}0-10 \\
11-20 \\
>20\end{array}$ & $\begin{array}{l}2 \\
4 \\
7\end{array}$ & $\begin{array}{l}3 \\
5 \\
5\end{array}$ & $\begin{array}{l}\overline{3} \\
4\end{array}$ & $\begin{array}{l}1 \\
3 \\
3\end{array}$ & $\begin{array}{l}4 \\
2 \\
1\end{array}$ \\
\hline \multicolumn{6}{|c|}{ Exposure time (years) } \\
\hline $\begin{array}{l}0-10 \\
>10\end{array}$ & $\begin{array}{l}7 \\
6\end{array}$ & . & $\begin{array}{l}3 \\
4\end{array}$ & . & . \\
\hline \multicolumn{6}{|l|}{ Age (years) } \\
\hline $\begin{array}{l}24-40 \\
41-50 \\
51-61\end{array}$ & $\begin{array}{l}6 \\
4 \\
3\end{array}$ & $\begin{array}{l}6 \\
4 \\
3\end{array}$ & $\begin{array}{l}4 \\
2 \\
1\end{array}$ & $\begin{array}{l}4 \\
2 \\
1\end{array}$ & $\begin{array}{l}4 \\
2 \\
1\end{array}$ \\
\hline \multicolumn{6}{|c|}{ Total smoking (pack-years) } \\
\hline $\begin{array}{l}0 \\
1-10 \\
>10\end{array}$ & $\begin{array}{l}3 \\
5 \\
5\end{array}$ & $\begin{array}{l}2 \\
4 \\
7\end{array}$ & $\begin{array}{l}1 \\
3 \\
3\end{array}$ & $\begin{array}{l}\overline{2} \\
5\end{array}$ & $\begin{array}{l}2 \\
1 \\
4\end{array}$ \\
\hline \multicolumn{6}{|c|}{ Present smoking (cigarettes/day) } \\
\hline $\begin{array}{l}0 \\
1-15 \\
>15\end{array}$ & $\begin{array}{l}6 \\
3 \\
4\end{array}$ & $\begin{array}{l}6 \\
5 \\
2\end{array}$ & $\begin{array}{l}3 \\
3 \\
1\end{array}$ & $\begin{array}{l}3 \\
2 \\
2\end{array}$ & $\begin{array}{l}3 \\
2 \\
2\end{array}$ \\
\hline
\end{tabular}

a Job-matched referents.

b Referents for the test splicers. 
coffee consumption than the referents. As for alcohol consumption, use of prescribed medicine, infections during the last three months, off-work chemical exposure, chronic diseases, and diagnostic radiography, there were only minor differences between the exposed subjects and the matched referents. The mean exposure time in cable testing was 11 (range $1-20$ ) years; the test splicers had a mean employment time of 12 years, and the corresponding value for the engineers was 9 years.

Blood samples were collected by venipuncture. For each matched pair, the sampling was performed within $90 \mathrm{~min}$ on the same day. If one member of a matched pair suffered from an acute infection, the blood sampling was postponed until at least two weeks after recovery. Sample pairs were sent by mail to the Department of Occupational Medicine, Telemark Central Hospital, and analyzed with the same procedures that were used in a previous study (6). Cytogenetic scoring was performed by three persons, without knowledge of the exposure status of the subjects. Samples from the exposed subjects and the matched referents (duplets or triplets) were treated simultaneously and always scored by the same person.

The cytogenetic analyses included assays for sister chromatid exchanges, chromatid and chromosome aberrations, and aneuploidy. Sister chromatid exchanges were scored in 30 cells, and the other parameters in 200 cells, per person. In addition, chromosome aberrations were scored after deoxyribonucleic acid (DNA) synthesis and repair were inhibited in vitro with hydroxyurea and caffeine (7). Hydroxyurea and caffeine were both added at a concentration of $7.5 \cdot 10^{-2} \mathrm{M}$, together with colcemid $(0.3 \mu \mathrm{g}$ $\mathrm{ml}^{-1}$ culture medium) $3 \mathrm{~h}$ prior to harvesting. Since a considerably larger amount of cytogenetic damage per cell was expected than in conventional cultures, 50 cells per person were scored. For comparison purposes, the counts have been given as per 200 cells.
Statistical analysis was performed with the use of SPSS PC+ (statistical package for the social sciences, personal computer+), version 3.0 (8). Mean values and standard deviations were calculated. The levels of cytogenetic damage were compared by the Wilcoxon matched-pairs signed ranks test. Most of the tests were two-sided. However, in the evaluation of chromosome breaks, one-sided tests were found to be appropriate, considering the hypothesis of the study.

\section{Results}

Table 2 shows the cytogenetic parameters for all 13 employees in the high-voltage laboratory and for the referents. When all of the exposed employees were compared with the job-matched referents, no difference reached a level of statistical significance. The mean number of chromosome breaks among the test splicers was 2.1 , as compared with 1.1 among the job-matched referents $(P=0.17)$. The numbers of chromosome gaps, sister chromatid exchanges, and aneuploid cells were similar in all of the subgroups.

Table 3 shows the mean number of chromosome breaks among the employees in the cable test laboratory in relation to the work category, recent exposure to electromagnetic fields, and smoking. Five of the employees who had been on sick leave had been recently transferred to other departments or had administrative work only were defined as having no recent exposure. In the subgroup of three smoking test splicers with recent exposure, the mean number of chromosome breaks was 3.7 , as compared with 1.3 among the job-matched referents. These three test splicers smoked less than the referents did. The subgroups of the engineers were also compared with their matched referents. The number of subjects in each subgroup was small, and there were no differences that approached the level of statistical signifi-

Table 2. Cytogenetic parameters for employees in the high-voltage test laboratory and the referents - conventional cultures. ${ }^{\mathrm{a}}$

\begin{tabular}{|c|c|c|c|c|c|c|c|c|c|c|c|c|c|c|c|}
\hline & \multirow{3}{*}{$\mathrm{N}$} & \multicolumn{4}{|c|}{ Chromatid } & \multicolumn{4}{|c|}{ Chromosome } & \multirow{2}{*}{\multicolumn{2}{|c|}{$\begin{array}{l}\text { Aberrant } \\
\text { cells }\end{array}$}} & \multirow{2}{*}{\multicolumn{2}{|c|}{$\begin{array}{c}\text { Aneuploid } \\
\text { cells }^{b}\end{array}$}} & \multirow{2}{*}{\multicolumn{2}{|c|}{$\begin{array}{c}\text { Sister } \\
\text { chromatid } \\
\text { exchanges }^{c} \\
\end{array}$}} \\
\hline & & \multicolumn{2}{|c|}{ Gaps } & \multicolumn{2}{|c|}{ Breaks } & \multicolumn{2}{|c|}{ Gaps } & \multicolumn{2}{|c|}{ Breaks } & & & & & & \\
\hline & & Mean & SD & Mean & $\mathrm{SD}$ & Mean & SD & Mean & SD & Mean & SD & Mean & SD & Mean & SD \\
\hline $\begin{array}{l}\text { All exposed } \\
\text { Job-matched referents }\end{array}$ & $\begin{array}{l}13 \\
13\end{array}$ & $\begin{array}{l}5.2 \\
6.2\end{array}$ & $\begin{array}{l}3.7 \\
4.2\end{array}$ & $\begin{array}{l}0.9 \\
1.2\end{array}$ & $\begin{array}{l}1.3 \\
1.4\end{array}$ & $\begin{array}{l}1.0 \\
1.2\end{array}$ & $\begin{array}{l}0.8 \\
1.1\end{array}$ & $\begin{array}{l}1.5 \\
0.9\end{array}$ & $\begin{array}{l}1.6 \\
1.4\end{array}$ & $\begin{array}{l}2.6 \\
3.1\end{array}$ & $\begin{array}{l}2.8 \\
2.5\end{array}$ & $\begin{array}{l}5.0 \\
4.1\end{array}$ & $\begin{array}{l}3.7 \\
4.5\end{array}$ & $\begin{array}{l}6.0 \\
5.6\end{array}$ & $\begin{array}{l}1.3 \\
1.0\end{array}$ \\
\hline $\begin{array}{l}\text { Test splicers } \\
\text { Job-matched referents } \\
\text { Office referents }\end{array}$ & $\begin{array}{l}7 \\
7 \\
7\end{array}$ & $\begin{array}{l}6.4 \\
8.1 \\
8.0\end{array}$ & $\begin{array}{l}4.2 \\
5.0 \\
4.4\end{array}$ & $\begin{array}{l}1.4 \\
1.4 \\
0.6\end{array}$ & $\begin{array}{l}1.5 \\
1.5 \\
0.8\end{array}$ & $\begin{array}{l}0.7 \\
1.6 \\
0.4\end{array}$ & $\begin{array}{l}0.8 \\
1.1 \\
0.8\end{array}$ & $\begin{array}{l}2.1 \\
1.1 \\
1.9^{\circ}\end{array}$ & $\begin{array}{l}1.9 \\
1.7 \\
2.9\end{array}$ & $\begin{array}{l}3.6 \\
3.7 \\
2.6\end{array}$ & $\begin{array}{l}3.5 \\
2.9 \\
0.8\end{array}$ & $\begin{array}{l}7.0 \\
5.7 \\
7.1\end{array}$ & $\begin{array}{l}3.3 \\
4.5 \\
3.7\end{array}$ & $\begin{array}{l}5.9 \\
5.7 \\
6.8\end{array}$ & $\begin{array}{l}1.7 \\
1.1 \\
2.3\end{array}$ \\
\hline $\begin{array}{l}\text { Test engineers } \\
\text { Job-matched referents }\end{array}$ & $\begin{array}{l}6 \\
6\end{array}$ & $\begin{array}{l}3.7 \\
4.0\end{array}$ & $\begin{array}{l}2.6 \\
1.4\end{array}$ & $\begin{array}{l}0.3 \\
1.0\end{array}$ & $\begin{array}{l}0.5 \\
1.3\end{array}$ & $\begin{array}{l}1.3 \\
0.7\end{array}$ & $\begin{array}{l}0.8 \\
0.8\end{array}$ & $\begin{array}{l}0.8 \\
0.7\end{array}$ & $\begin{array}{l}0.8 \\
1.2\end{array}$ & $\begin{array}{l}1.5 \\
2.3\end{array}$ & $\begin{array}{l}1.2 \\
2.0\end{array}$ & $\begin{array}{l}6.2 \\
6.7\end{array}$ & $\begin{array}{l}3.9 \\
4.5\end{array}$ & $\begin{array}{l}6.1 \\
5.6\end{array}$ & $\begin{array}{l}0.7 \\
1.1\end{array}$ \\
\hline
\end{tabular}

a All parameters scored in 200 cells, except for sister chromatid exchanges (scored in 30 cells). No differences significant at the $P=0.05$ level (Wilcoxon, two-sided, exposed versus matched referents).

- Cells with more than 46 chromosomes.

- Exchanges per cell.

d Mean value 0.8 , if one outlier (>mean $+2 \mathrm{SD}$ ) with a value of 8 , is excluded. 
Table 3. Number of chromosome breaks in relation to work category, recent exposure to electromagnetic fields, and smoking - conventional cultures.

\begin{tabular}{|c|c|c|c|c|c|}
\hline & \multirow{2}{*}{$\mathrm{N}$} & \multicolumn{2}{|c|}{ Exposed } & \multicolumn{2}{|c|}{$\begin{array}{c}\text { Job-matchec } \\
\text { referents }\end{array}$} \\
\hline & & Mean & $\mathrm{SD}$ & Mean & SD \\
\hline All employees & 13 & 1.5 & 1.6 & 0.9 & 1.4 \\
\hline $\begin{array}{l}\text { Engineers } \\
\text { Test splicers }\end{array}$ & $\begin{array}{l}6 \\
7\end{array}$ & $\begin{array}{l}0.8 \\
2.1\end{array}$ & $\begin{array}{l}0.8 \\
1.9\end{array}$ & $\begin{array}{l}0.7 \\
1.1\end{array}$ & $\begin{array}{l}1.2 \\
1.7\end{array}$ \\
\hline $\begin{array}{l}\text { No recent } \\
\text { exposure }\end{array}$ & 5 & 0.8 & 0.8 & 0.8 & 1.3 \\
\hline Recent exposure & 8 & 2.0 & 1.8 & 1.0 & 1.6 \\
\hline $\begin{array}{l}\text { Engineers } \\
\text { Test splicers }\end{array}$ & $\begin{array}{l}3 \\
5\end{array}$ & $\begin{array}{l}0.7 \\
2.8\end{array}$ & $\begin{array}{l}0.6 \\
1.8\end{array}$ & $\begin{array}{l}0.3 \\
1.4\end{array}$ & $\begin{array}{l}0.6 \\
2.0\end{array}$ \\
\hline Nonsmokers & 6 & 0.7 & 1.2 & 1.2 & 1.5 \\
\hline $\begin{array}{l}\text { Engineers } \\
\text { Test splicers }\end{array}$ & $\begin{array}{l}3 \\
3\end{array}$ & $\begin{array}{l}0.3 \\
1.0\end{array}$ & $\begin{array}{l}0.6 \\
1.7\end{array}$ & $\begin{array}{l}1.3 \\
1.0\end{array}$ & $\begin{array}{l}1.5 \\
1.7\end{array}$ \\
\hline Present smokers & 7 & $2.3^{a}$ & 1.5 & 0.7 & 1.5 \\
\hline $\begin{array}{l}\text { Engineers } \\
\text { Test splicers }\end{array}$ & $\begin{array}{l}3 \\
4\end{array}$ & $\begin{array}{l}1.3 \\
3.0\end{array}$ & $\begin{array}{l}0.6 \\
1.6\end{array}$ & $\begin{array}{l}0.0 \\
1.3\end{array}$ & $\begin{array}{l}0.0 \\
1.9\end{array}$ \\
\hline
\end{tabular}

cance. In a comparison of all of the laboratory employees with the job-matched referents, the smokers showed a more than threefold increase in chromosome breaks. The mean values were 2.3 and 0.7 , respectively $(\mathrm{P}=0.04)$.

Table 4 shows the cytogenetic parameters after in vitro DNA synthesis and repair inhibition for all of the exposed employees and for the job-matched referents. All of the outcome parameters showed larger values than the conventional cultures did. The mean number of chromosome breaks among the exposed employees was twice that of the job-matched referents, 7.4 versus $3.7(P=0.08)$, while the other parameters showed only minor differences. The mean number of chromosome breaks was higher among the test splicers than among the job-matched referents (9.1 versus 5.1) $(\mathrm{P}=0.05)$. An effect of smoking was also present in this assay. [The mean number of chromosome breaks in the smoking splicers was 12.0 , and that of the smoking job-matched referents was 6.0 $(\mathrm{P}=0.05)]$.

\section{Discussion}

Previously, only one cytogenetic study of high-voltage laboratory workers has been reported (9). In that study workers in a university electricity laboratory had slightly elevated total chromosome changes and sister chromatid exchange rates than radiologists did. In the present study the hypothesis-generating observation from our previous study (6) was repeated. In both of these studies the frequency of chromosome breaks among test splicers divided by that of referents was approximately three. The elevated number of chromosome breaks seemed to be confined to smokers. In a Swedish study of electrical power switchyard workers (10) the number of chromosome breaks was, as in our study, the most elevated among exposed workers who were current smokers. The observed effect in the present study, using conventional cultures, was further strengthened by the results from DNA synthesis and repair inhibited cultures. Again the difference was mainly present among smoking test splicers as compared with their job-matched referents. Enhanced detection of cytogenetic damage with the use of this method has been shown for smokers (7). Previous in vitro studies have indicated that unrepaired DNA lesions exist in mutagen-treated cells until the cells enter mitosis. The repair of these lesions can be effectively inhibited in the $\mathrm{G} 2$ stage (the last $3 \mathrm{~h}$ in culture) $(11,12)$. Kihlman \& Andersson (13) have suggested that chromosome aberrations as such cause delay or block in the G 2 stage. The block is removed by caffeine, the result being an increased number of damaged cells in mitosis.

In their work, test splicers are exposed to electromagnetic fields, cable oils, organic solvents, and ozone. The size of this study does not permit any advanced statistical analysis of the importance of combined exposure. Our previous study (6) indicated

Table 4. Cytogenetic parameters for employees in the high voltage test laboratory and for the referents - inhibited cultures. ${ }^{a}$

\begin{tabular}{|c|c|c|c|c|c|c|c|c|c|c|c|}
\hline & \multirow{3}{*}{$\mathrm{N}$} & \multicolumn{4}{|c|}{ Chromatid } & \multicolumn{4}{|c|}{ Chromosome } & \multirow{2}{*}{\multicolumn{2}{|c|}{$\begin{array}{l}\text { Aberrant } \\
\text { cells }\end{array}$}} \\
\hline & & \multicolumn{2}{|c|}{ Gaps } & \multicolumn{2}{|c|}{ Breaks } & \multicolumn{2}{|c|}{ Gaps } & \multicolumn{2}{|c|}{ Breaks } & & \\
\hline & & Mean & $\mathrm{SD}$ & Mean & SD & Mean & SD & Mean & SD & Mean & SD \\
\hline $\begin{array}{l}\text { All exposed } \\
\text { Job-matched referents }\end{array}$ & $\begin{array}{l}13 \\
13\end{array}$ & $\begin{array}{l}29.2 \\
28.3\end{array}$ & $\begin{array}{l}11.2 \\
16.5\end{array}$ & $\begin{array}{l}16.9 \\
16.3\end{array}$ & $\begin{array}{r}9.5 \\
10.4\end{array}$ & $\begin{array}{l}6.2 \\
5.2\end{array}$ & $\begin{array}{l}6.9 \\
4.7\end{array}$ & $\begin{array}{l}7.4 \\
3.7\end{array}$ & $\begin{array}{l}8.1 \\
4.2\end{array}$ & $\begin{array}{l}19.1 \\
17.2\end{array}$ & $\begin{array}{r}7.5 \\
11.5\end{array}$ \\
\hline $\begin{array}{l}\text { Test splicers } \\
\text { Job-matched referents } \\
\text { Office referents }\end{array}$ & $\begin{array}{l}7 \\
7 \\
7\end{array}$ & $\begin{array}{l}29.7 \\
30.9 \\
33.1\end{array}$ & $\begin{array}{l}10.8 \\
21.4 \\
20.4\end{array}$ & $\begin{array}{l}22.3 \\
23.4 \\
17.7\end{array}$ & $\begin{array}{r}9.8 \\
8.8 \\
29.6\end{array}$ & $\begin{array}{l}6.3 \\
5.1 \\
6.3\end{array}$ & $\begin{array}{l}8.0 \\
5.0 \\
5.1\end{array}$ & $\begin{array}{l}9.1^{*} \\
5.1^{k} \\
10.9^{b}\end{array}$ & $\begin{array}{r}4.5 \\
4.5 \\
14.0\end{array}$ & $\begin{array}{l}24.0 \\
24.6 \\
14.9\end{array}$ & $\begin{array}{r}5.7 \\
10.7 \\
11.3\end{array}$ \\
\hline $\begin{array}{l}\text { Test engineers } \\
\text { Job-matched referents }\end{array}$ & $\begin{array}{l}6 \\
6\end{array}$ & $\begin{array}{l}28.7 \\
25.3\end{array}$ & $\begin{array}{r}12.8 \\
9.0 \\
\end{array}$ & $\begin{array}{r}10.7 \\
8.0 \\
\end{array}$ & $\begin{array}{l}4.1 \\
3.6\end{array}$ & $\begin{array}{l}6.0 \\
5.3\end{array}$ & $\begin{array}{l}6.1 \\
4.8 \\
\end{array}$ & $\begin{array}{l}5.3^{c} \\
2.0\end{array}$ & $\begin{array}{r}11.2 \\
3.4 \\
\end{array}$ & $\begin{array}{r}13.3 \\
8.7 \\
\end{array}$ & $\begin{array}{l}4.8 \\
3.9 \\
\end{array}$ \\
\hline
\end{tabular}

a All parameters scored in 50 cells, but for comparison purposes, given in 200 cells. No differences significant at the twosided $P=0.05$ level (Wilcoxon, exposed versus job-matched referents).

b Mean value 6.0 , if one outlier ( $>$ mean +2 SD) with a value of 40 is excluded.

c Mean value 0.8 if one outlier with a value of 28 is excluded.

* $P=0.05$, one-sided (exposed versus job-matched referents). 
that exposure to cable oils alone is not genotoxic, as the cytogenetic parameters in cable splicers doing field installation did not differ from those of referents. Exposure to cable oils and organic solvents is higher among installation splicers than among laboratory test splicers. As for the significance of exposure to ozone, one study (9) indicated that the ozone levels experienced in high-voltage laboratory work are not related to any increased risk of chromosome damage. The workers in the high-voltage test laboratory were exposed to various electric and magnetic fields, as well as to spark discharges. The $50-\mathrm{Hz}$ magnetic fields during both $\mathrm{DC}$ and $\mathrm{AC}$ testing are comparable to fields experienced by people living close to power transmission lines. At present, the evidence for cytogenetic damage from such exposure levels is lacking (1). However, occasional exposure is considerably higher, when cables are touched during long-time cable testing. In addition, the pulsed electric and magnetic fields experienced during pulse testing differ from the experience of most other workers in our society.

In a Swedish study of 20 high-voltage substation maintenance workers, indications of work-related reproductive hazards were found (14). This result was followed up in two studies of power substation workers exposed to electromagnetic fields with transient currents $(10,15)$. The results from both studies were pooled, and an increased number of chromosome aberrations was found. Electromagnetic fields and electric discharges were considered to be the most probable causes of the findings. In contrast to the Swedish study, another human study of $380-\mathrm{kV}$ switchyard workers showed no damage to chromosomes (16). It has been argued that the level of exposure was not the same in the two studies.

Several in vitro studies of human lymphocytes exposed to pulsed alternating electromagnetic fields have shown increased numbers of chromosome aberrations (17-19), but some studies have been negative $(20,21)$. Sister chromatid exchanges were usually not elevated $(21-23)$, except after longer exposure times (17).

\section{Concluding remarks}

In summary of the literature and the present study, it seems that electromagnetic fields may be capable of producing chromosome aberrations, but not elevated sister chromatid exchanges in human lymphocytes, depending on the type and dose of electromagnetic field exposure. Our study and the Swedish studies are unable to exclude spark discharges as a causal factor. Until further studies of similar exposures are published, cable test employees should be advised to avoid unnecessary exposure to electromagnetic fields during pulse testing and not to touch the cable during long-time tests. They should also avoid spark discharges by sufficiently grounding the cables after testing.

\section{Acknowledgments}

We would like to thank Mr G Rekdal for information about the cable testing equipment and his positive support. Ms H Sødem collected the blood samples. Ms V Haugan and Mr KO Clausen participated in the cytogenetic analyses.

This project received financial support from Alcatel Kabel Norge and the Norwegian Cancer Society.

\section{References}

1. World Health Organization (WHO). Magnetic fields. Geneva: WHO, 1987. (Environmental health criteria; no 69.)

2. Ahlbom A. A review of the epidemiologic literature on magnetic fields and cancer. Scand $J$ Work Environ Health $1988 ; 14,337-43$.

3. Milham S. Mortality in workers exposed to electromagnetic fields. Environ Health Perspect 1985;62, $297-300$.

4. Delgado JMR, Leal J, Monteagudo JL, Garcia MG. Embryological changes induced by weak, extremely low frequency electromagnetic fields. J Anat 1982; 134:533-51.

5. Berman E, Chacon L, House D, Koch BA, Koch WE, Leal J, et al. Development of chicken embryos in a pulsed magnetic field. Bioelectromagnetics 1990;11: $169-87$.

6. Skyberg K, Hansteen I-L, Jelmert $\emptyset$, Rønneberg A. A cytogenetic and haematological investigation of oil exposed workers in a Norwegian cable manufacturing company. Br J Ind Med 1989;46,791-8.

7. Jelmert, Hansteen I-L, Langård S. Enhanced cytogenetic detection of previous in vivo exposure to mutagens in human lymphocytes after treatment with inhibitors of DNA-synthesis and DNA-repair in vitro. Mutat Res. In press.

8. Norusis MJ. SPSS/PC+ V2.0 base manual and SPSS/ PC+ V3.0 update manual. Chicago, IL: SPSS Inc, 1988.

9. Yang B. An analysis of sister chromatid exchanges in the lymphocytes in peripheral blood stream of the staff in high-voltage laboratories [in Chinese]. Chongqing University Acta 1985;1:31-8. (Summary in English.)

10. Nordenson I, Hansson Mild K, Nordström S, Sweins A, Birke E. Clastogenic effects in human lymphocytes of power frequency electric fields: in vivo and in vitro studies. Radiat Environ Biophys 1984;23,191-201.

11. Palitti F, Tanzarella C, Degrassi F, De Salvia R, Fiore M, Natarjan AT. Formation of chromatid-type aberrations in G 2 stage of the cell cycle. Mutat Res 1983; 110:343-50.

12. Palitti F, Tanzarella C, Degrassi F, De Salvia R, Fiore $M$. Enhancement of induced sister chromatid exchange and chromosomal aberrations by inhibitors of DNA repair processes. Toxicol Pathol 1984;12:269-73.

13. Kihlman BA, Andersson HC. Effects of inhibitors of DNA repair on the frequencies of chromosomal aberrations induced by X-rays or alkylating agents in cultured human lymphocytes. Prog Clin Biol Res 1986;209A:395-402.

14. Nordström S, Birke E, Gustavsson L. Reproductive hazards among workers at high voltage substations. Bioelectromagnetics 1983;4:91-101.

15. Nordenson I, Hansson Mild K, Östman U, Ljungberg H. Chromosomal effects in lymphocytes of $400 \mathrm{kV}$ substation workers. Radiat Environ Biophys 1988;27: $39-47$.

16. Bauchinger MR, Hauf R, Schmid E, Dresp J. Analysis of structural chromosome changes and SCE after 
occupational long-term exposure to electric and magnetic fields from $380 \mathrm{kV}$-systems. Radiat Environ Biophys $1981 ; 19: 235-8$.

17. Khalil AM, Quassem W. Cytogenetic effects of pulsing electromagnetic field on human lymphocytes in vitro: chromosome aberrations, sister-chromatid exchanges and cell kinetics. Mutat Res 1991;247:1416.

18. Ardito G, Lamberti L, Bigatti P, Prono G. Influence of a constant magnetic field on human lymphocyte cultures. Boll Soc Ital Biol Sper 1984;60:1341-6.

19. García-Sagredo JM, Monteagudo JL. Fffect of lowlevel pulsed electromagnetic fields on human chromosomes in vitro: analysis of chromosomal aberrations. Hereditas 1991;115:9-11.

20. Cohen MM, Kunska A, Astemborski JA, McCulloch D, Paskewitz DA. Effect of low level, $60-\mathrm{Hz}$ electromagnetic fields on human lymphoid cells: I. mitotic rate and chromosome breakage in human peripheral lymphocytes. Bioelectromagnetics 1986;7:415-23.

21. Rosenthal M, Obe G. Effects of 50-Hertz electromagnetic fields on proliferation and on chromosomal alterations in human peripheral lymphocytes untreated or pretreated with chemical mutagens. Mutat Res 1989;210:329-35.

22. García-Sagredo JM, Parada LA, Monteagudo JL. Effect on SCE in human chromosomes in vitro of lowlevel pulsed magnetic field. Environ Mol Mutagen $1990 ; 16: 185-8$

23. Cohen MM, Kunska A, Astemborski JA, McCulloch D. The effect of low level $60 \mathrm{~Hz}$ electromagnetic fields on human lymphoid cells: II. sister-chromatid exchanges in peripheral lymphocytes and lymphoblastoid cell lines. Mutat Res 1986;172:177-84

Received for publication:13 February 1992 